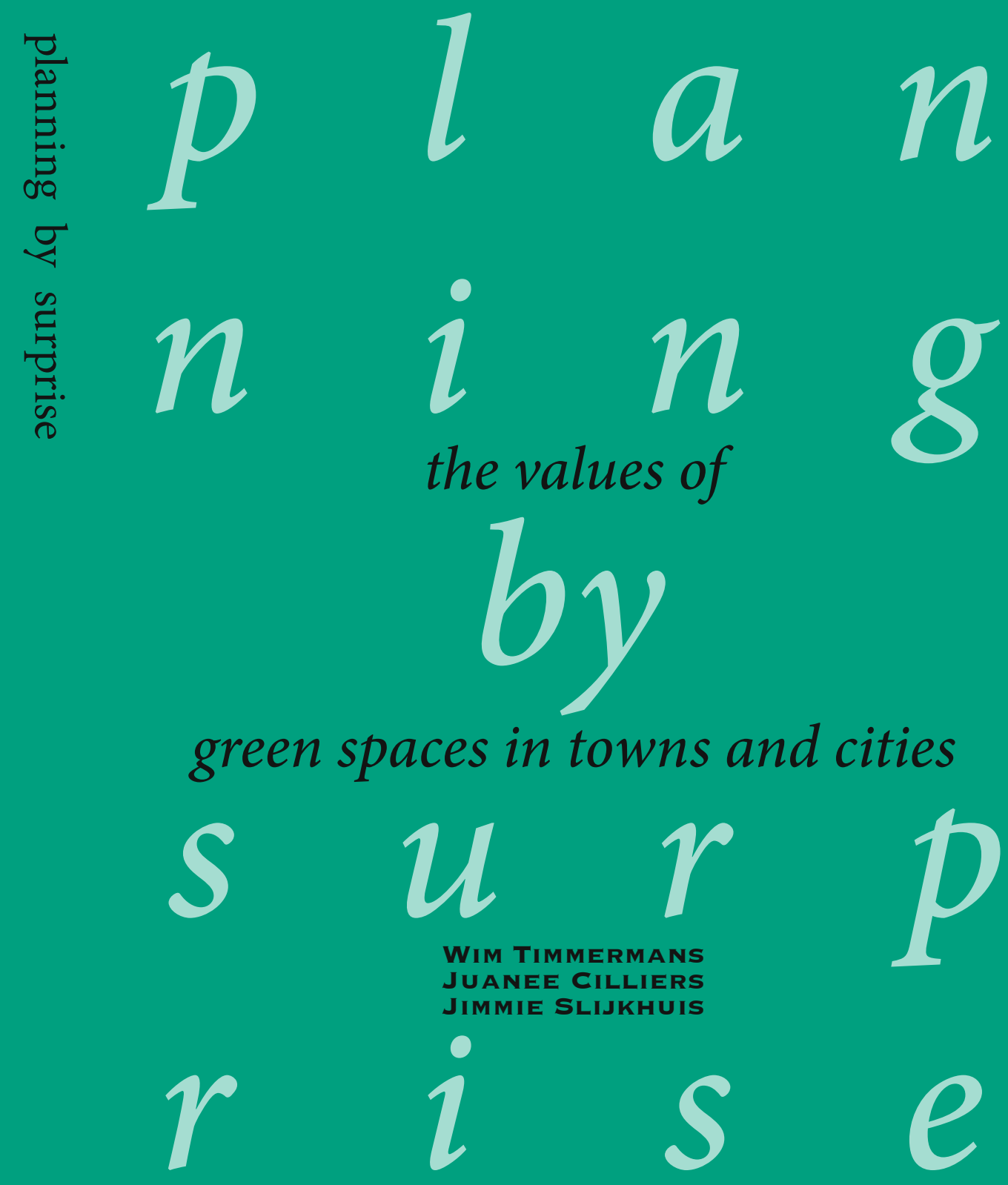



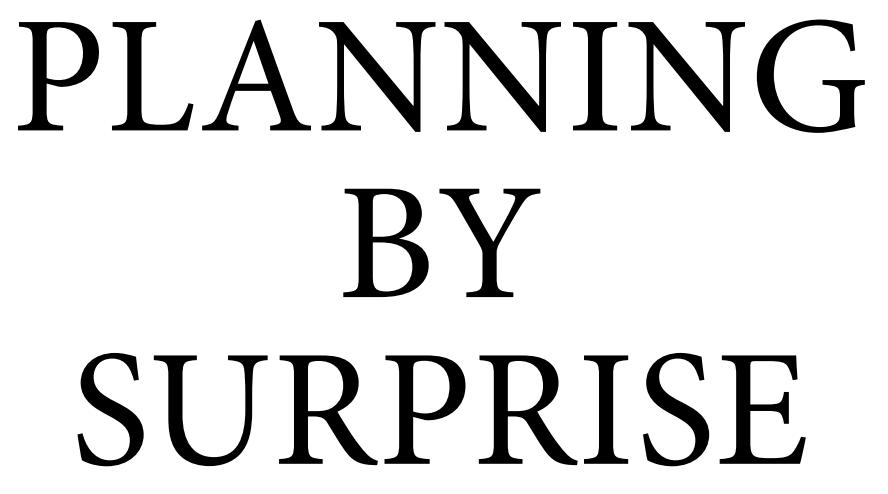

\title{
The values of green spaces in towns and cities
}

Wim Timmermans

\author{
Juanee Cilliers \\ Jimmie Slijkhuis
}




\section{PLANNING BY SURPRISE}

THE VALUES OF GREEN SPACES IN TOWNS AND CITIES

\section{AUTHORS}

Wim Timmermans

Juanee Cilliers

Jimmie Slijkhuis

EDITOR

Martin Woestenburg

DESIGN

Jos Jonkhof / Jonkhof Onderzoek\&Services

Fonts: Cambria, Minion, Copperplate, Palatino

PHOTOGRAPHY

Photo editor Jos Jonkhof

Photos by Jos Jonkhof, 6 by Peter Visschedijk

\section{PRINTED BY}

Druk. Tan Heck, Delft, The Netherlands

Paper: Bio Top 3, 100gr. (text) and

Satimat Green, 135gr. (photography)

\section{ISBN}

978-90-6824-036-8

DOI

$10.31715 / 2018.10$

A publication of Van Hall Larenstein, University of Applied Sciences, and the VALUE project.

VALUE stands for 'Valuing Attractive Landscapes in the Urban Economy' and is a project funded

by the European Union Interreg IVB programme for north-western Europe.

http://www.value-landscapes.eu/



VAN STEDEN

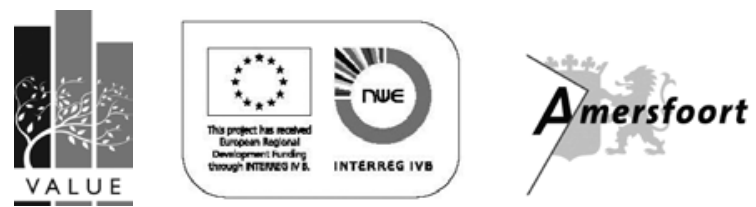


This booklet reports on experiments carried out by Van Hall Larenstein University of Applied Sciences in the context of the VALUE project. It consists of three parts. The first two chapters describe some experiments carried out in the Dutch town of Amersfoort and the students' input and approach. This is followed by an intermezzo on sources of inspiration outside the Netherlands and examples of the way urban green spaces and elements can provide an impulse for towns and cities. The final two chapters concern the way such a green strategy can be designed in Dutch urban settings. Chapter 5 discusses how local governments can use the added value provided by urban green spaces for new investments: value capturing. Chapter 6 focuses on a new type of planning: Planning by Surprise, which combines dreams and pragmatism. The photo essay at the centre of the book tells the story of the many sides of green spaces in towns and cities. Unintentional, intentional, planned, dreamed of, drawn, remembered, pictured, developed: Planning by Surprise.

The authors 


\section{PLANNING BY SURPRISE}

1 INTRODUCTION

Can urban green spaces be profitable?

Learning from experiments

Planning instruments

How can urban green spaces be measured?

What do the residents want?

How can the economic value of urban green spaces be captured?

Experiments

\section{PRACTICAL EXAMPLes: AMERSFOORT}

Randenbroek Park suits an urban green strategy

Value Added Planning

Quality improvement for the Euterpeplein square

Green Credit Tool

Timing is important

Drawing and calculating rolled into one

3 STUDENT WORKSHOPS AS A PRESSURE COOKER

Cycling

Context

Beers and debates
4 EXPERIENCES IN OTHER COUNTRIES: GREEN SPACES

CHANGING TOWNS AND CITIES AND ACTING AS A CATALYST

FOR THE URBAN ECONOMY

Parks at the centre of neighbourhood life

Community gardens

Ten years of experimenting

Not just copy and paste

5 REAPING WHAT YOU SOW

Value capturing

Cashing in and investing at the same time

Rethinking financing and planning

6 PlanNing by SURPRISE: GREen SPACES SETTING AGENDAS

Technical and communicative planning

Chance and surprise

Feelings, impressions, coincidence, personal

relationships and

political changes

Depending on 'soft' information

Beliefs and pragmatism

Planning by surprise

PUBLICATIONS BY VAN HALL LARENSTEIN, UNIVERSITY OF APPLIED SCIENCES, IN THE VALUE PROJECT 


\section{INTRODUCTION}

Urban green spaces make for healthy, liveable, economically viable, clean and attractive towns and cities, but are also of economic interest, as they make a town or city more attractive to new businesses. The European VALUE project (Valuing Attractive Landscapes in the Urban Economy) involved ten partners ${ }^{\bullet}$ which collaborated between 2008 and 2012 to collect evidence of the added economic value provided by green spaces in towns and cities.

- Sheffield City Council, Ge- The idea that urban green spaces are important for meente Amersfoort, Vlaamse towns and cities is generally accepted. Dutch towns Landmaatschappij, Hogeschool Van Hall Larenstein, University of Sheffield, Verband Region Stuttgart, Services Promotion Initiatives and province de Liège, Université de

Liège, Institut für Landes- und Stadtentwicklungsforschung und Bauwesen des Landes

Nordrhein-Westfalen and Community Forest North West.

and cities eagerly compete for the title of 'Greenest Town', estate agents sing the praises of green residential neighbourhoods, parks are increasingly being used as sites for lounging around or jogging, property developers are using green spaces as a selling point, and research evidence is accumulating that green elements are good for human health, the environment and the urban climate.

These convictions have also come about as a result of the huge growth that towns and cities have shown over the last 50 years, which meant that green elements were replaced by buildings and infrastructure. Existing urban green spaces were increasingly occupied by housing, infrastructure, industrial estates and other urban facilities, with all the accompanying unfavourable effects. Inevitably, people started to protest against these developments, in a defensive reaction that fitted in with the public's increasing environmental awa- 
reness at the end of the twentieth century. Meanwhile, green spaces have come to be highly valued, and towns and cities can no longer do without them.

\section{CAN URBAN GREEN SPACES BE PROFITABLE?}

The added economic value provided by urban green spaces has become more important over the last ten years, a process that was further stimulated by the current economic crisis. Towns and cities with large, well-tended and functional green spaces are often also the ones that are regarded as attractive places to live, work and spend one's leisure time in. This means that urban green spaces make for a pleasant social climate, making them economically and financially valuable by enhancing a town's competitive advantage.

Hence, local governments will want to invest in urban green spaces not merely to prevent urban degradation but especially to enhance a town's economic position within its regional urban network, within the country and within Europe. The question then arises, however, whether investing in urban green spaces will actually pay off. The problem is that the added value provided by urban green spaces is hard to express in monetary terms. Although there is evidence that green spaces contribute to human health, improve the environment, bring people together and increase the market value of houses, one may wonder who profits from these advantages, and how these processes can best be managed. These were the questions that the VALUE project focused on.

\section{LEARNING FROM EXPERIMENTS}

In the context of the VALUE project, research institutes and local authorities have collaborated in recent years to develop methods to express the value of urban green spaces in monetary terms, to involve citizens in this effort to value green spaces and to find out what strategies local authorities can design to ensure that the whole town or city benefits from the added value. The goal of this joint European project was that towns and cities would learn from each other's experiments and that public authorities would learn to collaborate and benefit from each other's knowledge and experience.

In the wider context, VALUE was about developing green strategies for towns and regions. The research in the VALUE project tried to answer the question where investments in green infrastructure in towns and regions would yield the greatest economic benefits, and how green infrastructure can at the same time help to improve the spatial quality of these towns and regions. The research was based on the idea that green infrastructure is of vital importance for the strength and prosperity of towns and cities in north-western Europe. The research was intended to create awareness of the value of green infrastructure.

\section{PLANNING INSTRUMENTS}

This publication concentrates on the collaboration between the Van Hall Larenstein University of Applied Sciences and the Amersfoort municipal authorities. Researchers and students at Van Hall Larenstein examined planning methods relating to the added economic value provided by urban green 
spaces. These methods were then tested in several experiments, in collaboration with the local authorities, focusing on the urban green spaces at the Euterpeplein square, the Randenbroek Park and the Vathorst district. The VALUE project focused on three planning instruments that can be used for green space strategies:

- The Green Credit Tool, used to establish the value of urban green spaces

- The Workbench Spatial Quality, used to involve residents, users and interest groups in planning

- Value Added Planning to maximise the added economic and social value of urban green spaces

\section{HOW CAN URBAN GREEN SPACES BE MEASURED?}

Determining the added economic value of urban green spaces obviously starts by looking at the available green spaces in towns and cities. This was done using the Green Credit Tool. The logical next step was to find out what the Amersfoort residents think of the green spaces in their town, which was assessed using the Workbench Spatial Quality instrument. Finally, the follow-up question of how the Amersfoort local government could use the added economic value in its policy planning efforts was addressed using the method of Value Added Planning.

The Green Credit Tool is a method to measure the value of urban green spaces. The method was developed by the Amersfoort municipal authorities, and was tested in the context of the VALUE project in several pilot studies. The method derives from the concept of 'nature compensation', which means that loss of natural habitats resulting from redevelopment projects can be compensated by creating or improving green spaces elsewhere or through financial compensation. The nature compensation principle has been laid down in EU legislation, and has also been included in Dutch national legislation, which implies that the Green Credit Tool has a legal basis.

The Green Credit Tool evaluates urban green spaces on the basis of seven aspects: use, perception, water and ecology, culture and architecture, management and maintenance status, land use and the value of the area. A matrix is then used to subdivide these quality aspects of urban green spaces into a number of subaspects that are relevant to the various target groups within a town or city. This makes the Green Credit Tool a suitable instrument to start discussions with local residents and other stakeholders about the consequences of constructing a new road, a new housing scheme, redesigning urban green space, etc.

\section{WHAT DO THE RESIDENTS WANT?}

The Workbench Spatial Quality, developed by the Habiforum network of planning experts, is actually a set of methods to enhance public participation, which are used to establish the added value provided by urban green spaces. The approach involves four phases, which interlink to form a circle. The first phase often involves a field trip through the area concerned to gauge the perceptions of all parties involved; in this process, all those involved are regarded as experts. The next step involves designing a quality profile of the area, with people giving it points for its use value, amenity value and future value. The 
third phase involves using scenarios, calculations, mapping and a layering approach to design a plan for the area. Phase four, finally, concerns the design and its realisation. The result is monitored, for instance in terms of the perceptions of the new situation by all those involved.

\section{HOW CAN THE ECONOMIC VALUE OF URBAN GREEN SPACES} BE CAPTURED?

Local authorities can use Value Added Planning to examine how investments in green infrastructure can produce added economic value for the rest of the town or city. It is based on the hard fact that house prices in leafy residential areas are 5 to $15 \%$ higher than elsewhere. The main question is how towns and cities that invest in a green residential environment can benefit from this added value.

Value Added Planning starts right at the beginning of the planning process, with the question whether urban green spaces actually provide added value, and whether the housing market offers opportunities to gain a profit from it. The Amersfoort situation was found to offer several opportunities. A specific green design could produce added economic value, and the local government can use modelling techniques for strategic utilisation of this added value produced by green space investments. Local authorities can collaborate with public and private parties to develop strategies that enable them to benefit from the increased value of houses in green residential areas. The project also examined what urban green spaces meant for future spatial planning in Amersfoort.

\section{EXPERIMENTS}

This booklet reports on experiments carried out by Van Hall Larenstein University of Applied Sciences in the context of the VALUE project. It consists of three parts. The first two chapters describe some experiments carried out in the town of Amersfoort and the students' input and approach. This is followed by an intermezzo on sources of inspiration outside the Netherlands and examples of the way urban green spaces and elements can provide an impulse for towns and cities. The final two chapters concern the way such a green strategy can be designed in Dutch urban settings. Chapter 5 discusses how local governments can use the added value provided by urban green spaces for new investments: value capturing. Chapter 6 focuses on a new type of planning: Planning by Surprise, which combines dreams and pragmatism. 


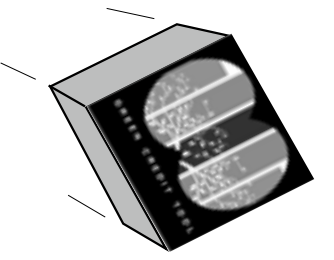

The Amersfoort local authorities and students of Van Hall Larenstein University of Applied Sciences have carried out experiments at two sites, the Randenbroek Park and the Euterpeplein square, to find out how the added economic value of urban green infrastructure can be maximised. The experiments showed that there is a need for ways to combine the actual process of drawing a design with calculations on investments, while focusing on the planning process.

Right from the start, the Amersfoort local authorities emphasised the contributions of residents, users and other relevant interest groups. The authorities had already intended to apply the Value Added Planning approach to the green strategy for the Randenbroek Park to maximise the added economic value of this urban green space. It also intended to consult the general public using the Workbench Spatial Quality. In the case of the Euterpeplein square, the authorities intended to use the Green Credit Tool to assess the value of the area and the green elements, in consultation with residents, users and other interest groups. These ideas were introduced as elements in the European VALUE project. The Van Hall Larenstein University of Applied Sciences was asked to help test the theory of the three planning instruments described above in Chapter 1 in the practical conditions of the town of Amersfoort. 
RANDENBROEK PARK SUITS AN URBAN GREEN STRATEGY

Satellite images clearly show that the Randenbroek Park is one of the larger green spaces in Amersfoort. The present park represents the remains of a seventeenth-century country estate, and is surrounded by sports fields and the St. Elisabeth hospital, situated in the valley of the Heiligenbergerbeek brook, which enters the town from the south.

In the year 2000, the hospital and a tennis club decided to move to different locations, and various sports clubs announced plans to expand their grounds and add new facilities, so the local authorities were forced to think about redesigning the park. The Amersfoort authorities were faced with two challenges, developing a green leisure area along the brook valley and redeveloping the old hospital buildings. The authorities decided from the start to develop a whole green infrastructure strategy for the entire area from the Randenbroek Park to the A28 motorway. The point of departure for the redevelopment of the hospital grounds was that the construction of the new hospital, called Meander Medical Centre, and the relocation of the St. Elisabeth hospital and the Lichtenberg hospital to the new location, would not require additional investments. Specifically, this meant developing plans for housing construction in the former St. Elisabeth grounds. The plans were designed to include as much green space along the brook as possible.

\section{Value Added Planning}

Right from the start of the Randenbroek planning process, in the year 2000, the Amersfoort local authorities began to use the Value Added Planning method. It soon turned out that political decision-making was a very important element in this process. The original idea was that the St. Elisabeth hospital buildings would be turned into apartments by a housing corporation, and that the proceeds would be used to fund green infrastructure development. This changed in 2010, when a newly elected municipal executive decided that the former hospital grounds should also become part of the park. This led to a plan for a 65 ha green space, a 'green lung' for Amersfoort.

The Workbench Spatial Quality was used in the Randenbroek development project in order to ensure that not only ecological and historical values but also economic interests and values would be assessed. Thus, the green redevelopment scheme for the Randenbroek Park became part of a fundamental debate on the town's green infrastructure strategy, involving many interests and many stakeholders.

\section{QUALITY IMPROVEMENT FOR THE EUTERPEPLEIN SQUARE}

The Euterpeplein square presented a completely different challenge. Euterpeplein is a triangular space situated in the post-WWII residential neighbourhood of Schuilenburg. The square was used as a car park, lined with trees and surrounded by shops and houses, and some streets with busy traffic. Its spatial quality was poor, and the trees on the square were in poor health. 
The local authorities decided that this situation had to be improved. Their ambition was to increase the value of the green elements, including their aesthetic quality, their use quality, their ecological and cultural quality, as well as the quality of maintenance. The authorities used the Green Credit Tool to check whether this ambition was actually realised. They had already been using this instrument to make decisions about maintaining, replacing, relocating or removing green elements at smaller sites. Researchers and students of Van Hall Larenstein University of Applied Sciences advised the authorities on the use of the Green Credit Tool.

\section{GREEN CREDIT TOOL}

The Green Credit Tool tied in with the seven-step process of citizen participation that the local authorities were using in the Schuilenberg area. This process started with consultations with known stakeholders, followed by listening to and contacting residents, entering into discussions with them in order to deepen understanding, involving residents in the planning process, discussing options for the further process, formal consultations required by law and finally a tour of the neighbourhood in an old bus, using a video camera to record people's reactions.

The Green Credit Tool was used to assess the value of the square and to evaluate the design produced on the basis of consultations. This was done by consulting neighbourhood residents, businesses and organisations through a questionnaire about the existing green elements and their preferences for future green elements. The various aspects of quality (use, perception, water and ecology, culture and architecture, management and maintenance status, land use and the value of the area) were then entered into a matrix, which could be used to estimate the quality of the future green elements for the local residents, businesses and organisations.

The conclusion was that the new plans for the Euterpeplein square would result in green elements with a quality that would be at least equal to that of the existing situation and might have a positive effect. The process evaluation showed that the response rate to the questionnaire was fairly low, and that residents found it hard to make objective judgements about the trees in the square. The removal of old trees was a sensitive issue, even if they were to be replaced by new, healthy trees that would in the longer term result in a higher quality of the square. People's subjective perspective largely prevented them from looking objectively at the future qualities of the intended green elements

\section{TIMING IS IMPORTANT}

It turned out to be important to apply policy instruments like Value Added Planning, Workbench Spatial Quality and Green Credit Tool at the right moment. Timing is important, and their implementation should start sooner rather than later. With hindsight, for instance, the Workbench Spatial Quality should have been used much earlier in the process. This would have resulted in more planning options, and would have involved the residents, users and other interest groups in the decisionmaking process about the final plans at a much earlier stage. 
The Green Credit Tool was also used too late in the Euterpeplein planning process, namely after the design had already been made. With hindsight, it would have been better to apply this instrument at an earlier stage of the design process, as this would have made it possible to incorporate the results of the study more effectively in the design for the green elements in the square. If the Green Credit Tool is not used right from the start of the process, it merely becomes an instrument to defend or explain decisions that have already been made. Another recommendation to improve the public's involvement is to avoid specialist jargon and unfamiliar terminology. This means that the questionnaire should be tailored to the intended respondents' experiential world.

\section{DRAWING AND CALCULATING ROLLED INTO ONE}

The experiment on Randenbroek Park has shown that it is very difficult to directly calculate the added value of more green space in the area of the park and the former hospital, as this added value is not confined to the site where the developments take place, but is particularly dependent on developments in the wider context. The added value provided by urban green spaces depends not only on local political, administrative and economic conditions, but also on countrywide developments on the housing market and in the national economy.

The use of Value Added Planning implies that design drawings and calculations are produced simultaneously in order to find the spatial quality that will maximise the economic value. This enables the local authorities to use an indirect approach to look for added economic value. Since it is the residents, users and other interest groups that benefit most from the new park development, it would seem logical to ask these parties to participate in the search for the added value of green space redevelopment.

The focus must be on the planning process itself, not on its immediate proceeds. This was the main conclusion that the Amersfoort local authorities drew about the use of Value Added Planning. Although direct economic gains from green infrastructure are hard to calculate, added value can be achieved by inviting a range of disciplines to become involved in the planning process right from the start.

Designers produce drawings, and economists produce calculations. This is not unusual, but the two processes rarely take place simultaneously. In many cases, the designers first produce the drawings, aiming for spatial quality, and then the economists come in to calculate the development costs, whereas what matters is the combination of drawing and calculating in a multidisciplinary planning process. This was also found during the student workshop, which is discussed, in the next chapter. 


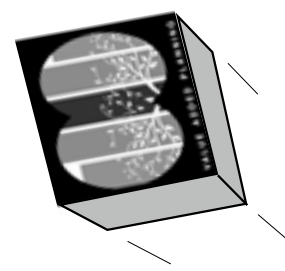

At Van Hall Larenstein University of Applied Sciences, a tried and tested method is to put students from various disciplines together in a kind of pressure cooker situation for a few days and ask them to come up with new plans for existing spatial challenges. In October 2011, therefore, 18 students stayed at a youth hostel in the village of Soest to study the problem of the Randenbroek Park in Amersfoort. They included urban development students from Saxion University of Applied Sciences, students of landscape architecture and planning from Van Hall Larenstein and students of real estate from Hanze University of Applied Sciences, who together addressed the question how green infrastructure could be used to create added value for the Randenbroek Park.

Student workshops at Van Hall Larenstein consist of a diverse programme of lectures, field trips, design sessions, provocative talks by guest speakers and a lot of debate, ultimately resulting in a presentation to the client. In the case of the Randenbroek Park, the client was the Amersfoort local government. The students were advised by Van Hall Larenstein lecturer Ad Koolen and Amersfoort municipal official Arno Goossens.

\section{CYCLING}

The workshop started on Wednesday 21 October with an introductory talk by Arno Goossens about the position of the Randenbroek Park in the municipal long-term vision on structural design planning. The redevelopment of the park fits in 
with the intentions to improve the quality of the Heiligenbergerbeek brook as the key element for ecology and leisure activities, and to create green corridors. After this introduction, Goossens and the students got on bikes and cycled along the three sites involved: a public swimming pool in the northern part of the area which was to be replaced by green space and urban villas, the old hospital in the middle part which was to be torn down and be replaced by two green spaces, and the site southeast of the brook where a new housing estate was planned. Six multidisciplinary groups of students were then put together to study these three sites. On Wednesday night, the students attended lectures by real estate expert Jan Bervaes and town and country planner Terry van Dijk of the Alterra research institute. These external experts talked about the relationships between buildings and green infrastructure in an urban context, each from their own professional perspective, which resulted in contradictory views. Bervaes explained that the value of a house increases by $10 \%$ if it has a water body at the back, whereas a water body in front of the house hardly affects its price at all. He also mentioned that people appreciate the opportunity to go for a short walk near their own home, which is rarely available. Van Dijk expressed doubt about actually realising the added economic value of green housing estates, as efforts to reap such financial benefits are expensive and attended by legal problems.

\section{CONTEXT}

Thursday was the day when the actual planning session took place. The six groups of students were invited to put their ideas to paper, and the first draft designs were produced. A striking aspect was that several of the groups started looking for more context. Adjoining groups would often come over to look at and talk about each other's work. There were also considerable differences in the students' way of thinking. Students of landscape architecture tended to focus on the opportunities offered by the area, while the urban development students looked first and foremost at feasibility. The groups did, however, find some common ground with regard to the three sites: the key element at the swimming pool site was the country house, while the Heiligenbergerbeek brook was the main connecting line at the hospital site, and green corridors were considered by all to be essential for the new housing estate site.

In the evening, the students listened to talks by two further external experts: Frank van Genne, lecturer in real estate management at Saxion University of Applied Sciences and Rüdiger Amend, landscape architect at the LA.BAR agency in Berlin. Van Genne claimed that it is possible to predict how people will respond to a particular residential environment, and whether they will want to live there. 'People make choices that enable them to show who they are and where they belong.' That is why it is so important to think about the target group for which one is producing a design. Amend told the students about his experiences with Value Added Planning, the method that the Amersfoort municipal authorities also used to realise the added value produced by urban green spaces. He mentioned the option of having residents use temporarily unused derelict sites, for instance to grow vegetables. 
In Berlin, this had led to debates about possibly designating such sites as permanent open spaces.

\section{BEERS AND DEBATES}

The pressure cooker situation then proved its value. The landscape architecture students took the lead in producing a draft design, with students of real estate critically evaluating the way the designers interpreted the economic added value offered by urban green spaces in their own special way. After a few beers or glasses of wine, heated debates arose as the evening wore on, with the real estate students contributing what they are good at: they were the ones who could do the maths for the designs that the others came up with.

The Thursday night debates gave the students not only a new, fresh outlook on the challenges, but also led to new relations and a new division of labour between the disciplines. In their final design session, the groups first concentrated on the financial basis, puzzling over numbers of houses, demolition costs and locations for new buildings that would maximise the financial outcome. The Internet and the students' own files were consulted to find suitable reference images. The groups also developed a clear internal division of labour, with the landscape architects taking care of the design, the real estate students calculating the added economic value provided by the urban green spaces, and tasks being generally divided as efficiently as possible.

As a result, the groups of students joined forces to decide where, but especially why they wanted to develop something at a particular site. The new type of partnership led to a more solidly based story and a clearer concept, with students working late into the night to prepare their presentations for the next day.

After the presentations about the three sites on Saturday, there was a lively debate with the Amersfoort municipal officials, who were pleasantly surprised by the amount of work the students had done within such a short space of time. 


\section{EXPERIENCES IN OTHER COUNTRIES: GREEN SPACES CHANGING TOWNS AND CITIES AND ACTING AS A CATALYST FOR THE URBAN ECONOMY}

Several examples from other countries have shown how green spaces can breathe new life into the urban fabric. Three examples from France and Germany illustrate how a town or city can come to life after investments in green infrastructure. Obviously, these examples could not be simply adopted in the Netherlands without further adaptation; it is not a matter of copy and paste. Dutch local governments will have to come up with their own green planning, and will have to calculate the added value provided by green spaces, using the instruments and planning options described in this brochure.

PARKS AT THE CENTRE OF NEIGHBOURHOOD LIFE

The Promenade Plantée was originally a viaduct for a narrowgauge railway line from the Place de la Bastille in Paris to the Bois de Vincennes. The line was operational from the nineteenth century up to its final closure in 1969. When the Bastille station was demolished in 1984 to make room for the new Opéra Bastille, funds were also made available for the construction of the Promenade Plantée. This involved renovating arcades and integrating the remaining banks, viaducts, buildings and tunnels into the promenade. By 1993, this had resulted in an almost 5 kilometre long green promenade, varying in width from 9 to $30 \mathrm{~m}$ and running from the $10 \mathrm{~m}$ high Viaduc des Arts with its art shops near the Place de la 
Bastille to the Jardin de Reuilly near Rue Montgallet, where it descends to ground level.

But this was only the beginning. At first, the buildings around the promenade stood, as it were, with their backs to the railway viaduct, without any windows on that side, as noise and dust had always had to be kept out. After the greening of the line, the surrounding buildings were fitted with windows and balconies offering a view of the green promenade from the apartments. As a result, the railway viaduct became the green heart of the surrounding neighbourhoods. House prices rose, the neighbourhoods became more attractive places to live and work in, and new businesses moved in.

Since then, the concept of the Promenade Plantée has been successfully applied in New York for the redevelopment of the High Line, the most striking new element being the new Standard Hotel built on top of a viaduct. The success of the Promenade Plantée has induced cities like Chicago, Philadelphia and St. Louis to develop plans for the greening of disused railway lines. In Rotterdam, plans are being designed for the Hofbogen arcade underneath the viaduct of the disused Hofplein line. Such projects are seen as potential catalysts of urban life and as a major impulse for the economy of the surrounding neighbourhoods.

\section{COMMUNITY GARDENS}

Projects at a very different scale are the Jardins Partagés, temporary gardens, kitchen gardens and mini-parks that are being created at sites where there is a temporary lull in the continuing construction work that goes on in a city. This usa- ge arose in France in the nineteenth century, when 'labourers' gardens' were developed to feed the people.

It is a simple idea. In any town, there will often be sites available where no building activity is expected to take place for a while. The local government helps the residents design and plant their urban garden by providing information, materials and supervision. It concludes a contract with the residents stipulating clear rules for the temporary use of the garden. This creates certainty for the local authorities and the property developers, as well as for the residents who maintain and use the garden. Paris now has over 40 Jardins Partagés, and the phenomenon has spread to the whole of France. The first modern examples are the Community Gardens in New York, which currently number about 750. A first buurtuin or neighbourhood garden in the Netherlands was laid out in the town of Maastricht in 2010 .

\section{TEN YEARS OF EXPERIMENTING}

Experiments have always been at the basis of the concept of the Internationale Bauausstellung (IBA) exhibitions in Germany. This planning instrument was first used in Darmstadt in 1901. When an IBA is held, the regional authorities invest in spatial planning experiments that can be expected to yield social, economic, cultural and ecological impulses for the region, for a maximum of ten years. After these ten years, successful experiments are expected to survive without further assistance.

A well-known example is the IBA Emscher Park in the Ruhrgebiet region, from 1989 to 1999. This region was characterised 
by declining mining operations and heavy industries, and the large-scale mining operations had caused natural water tables to sink to great depths and surface waters to disappear. Joint regional efforts led to an international exhibition or the reuse of industrial heritage sites, introducing new businesses in the services sector and converting the industrial landscape into a landscape park. The immediate starting point was the effort to restore natural water levels to the region, but ten years of experimenting was found to lead to an economic revival of the region as well.

The IBA method is an ongoing process, with newly started projects learning from ongoing or completed IBAs. The IBA at the former lignite mines in Fürst-Pückler-Land was recently concluded, and new projects have started near Hamburg, Basel and Thüringen. In the Netherlands, authorities at Parkstad Limburg, a region with a shrinking population near the borders with Germany and Belgium, are setting up IBA Parkstad.

\section{NOT JUST COPY AND PASTE}

The Promenade Plantée, Jardins Partagés and IBAs are inspiring examples. So inspiring, in fact, that many foreign public authorities, designers and researchers have visited them, and the projects are even beginning to be imitated in the $\mathrm{Ne}$ therlands. However, a word of caution is called for here. The promenade and community gardens in Paris and the exhibitions in Germany derive from a completely different political and administrative situation. For instance, France has a minister for urban affairs, and in Germany, government investments are used to drive spatial and economic developments, whereas in the Netherlands, towns and cities are left to their own devices when it comes to green infrastructure. The Dutch national government has now formally decided to withdraw from spatial planning and policies on nature and the landscape, but in fact it had kept its distance from town and city level issues and policies long before. Investing in green infrastructure has always been a matter for the municipal authorities, although the national government did set policies for buffer zones, conservation areas and leisure areas.

In fact, this is what makes the instruments described in this brochure relevant. Although the ideas from Paris and Germany may be highly suitable for certain Dutch towns or cities, or for a region where the authorities of various municipalities have entered into partnerships, the authorities will have to come up with practical ways to realise them. Some suggestions for this are made in the following chapters. 
Although municipal area development projects often involve investments by local governments in green spaces and water bodies around new buildings, these governments rarely reap the benefits of their investments. Although the presence of parks, green belts, open space and water bodies around buildings increases the monetary value of the real estate by an estimated 6 to 15 percent, this added value is usually collected by the property developers and real estate owners, and is later traded. Although green spaces are important for local authorities as part of the marketing mix by which they try to make their town or city attractive to new businesses and residents, as well as to improve liveability, the authorities often lack the resources to actually develop and maintain green spaces. In addition, there was until recently not a great deal of interest in the added value produced by investments by local authorities in green spaces.

\section{VALUE CAPTURING}

There is currently a growing awareness, however, that investments by local governments can increase the monetary value of real estate. This awareness has led to the concept of value capturing, a collective term for instruments to ensure that the added value of real estate caused by investments by the authorities in green spaces and water bodies is partly returned to the authorities who invested the money.

Value capturing goes beyond the quid pro quo principle of existing schemes to use profits from building works to invest 
in green infrastructure ('red for green' projects). The proceeds from real estate development are used to fund habitat creation and conservation, but the newly created habitats or nature conservation measures do not necessarily have a direct relation with the buildings or infrastructure. Such schemes are more like compensation schemes in which the disappearance of natural habitats in one place is compensated by investments in nature elsewhere.

\section{CASHING IN AND INVESTING AT THE SAME TIME}

Value capturing involves a combination of cashing in and investing at the same time. On the one hand, it is a way for local governments to get a return on their investments in green spaces and water bodies, which increase the monetary value of real estate. On the other hand, it means using the proceeds for the kind of investments that yielded the added value. This results in a continuous process of investments to create green spaces that produce added monetary value, which in turn generates new financial resources for further investments in green spaces, etc.

This can only be achieved if there is an actual added value for real estate, which in practice requires situations with sufficient market pressure in the housing and real estate markets. Instruments for value capturing are already available, including the three instruments discussed above.

The use of such instruments can be made compulsory if the authorities in a particular town or city have sufficient opportunities to do so. If not, then voluntary public-private partnerships can be used, while taking account of the various long- term and short-term perspectives of parties such as property developers, housing corporations, investors and private real estate owners.

\section{RETHINKING FINANCING AND PLANNING}

Timing is of the essence in value capturing. There are two moments at which the monetary value of real estate increases, and at which the value capturing instruments can be applied. One is at the realisation stage, for instance when a house is sold, when the value of the real estate is higher if it is situated in a green environment than in an area without any green elements. The other moment occurs during the property management stage, when the green elements have reached full maturity and the property value has increased for parties that work from a long-term perspective, such as investors and housing corporations.

Value capturing requires a new way of thinking about financing and planning. Green elements have to be incorporated in the planning process at an early stage, so as to allow the opportunities to be correctly evaluated. The calculations should not be based on costs, but on investments and value. Although this means that value capturing requires rethinking various aspects, it can be used in area redevelopment schemes on the basis of a relatively simple five-step plan (see FIVE STEP PLAN diagram below), enabling local governments to actually reap what they have sown. 


\section{PRIMARY CONDITIONS}

- actual increase in Value of real estate

- SUfFICIENT PRESSURE ON HOUSING MARKET

- RELATIVELY SMALL INVESTMENT SHORTFALL

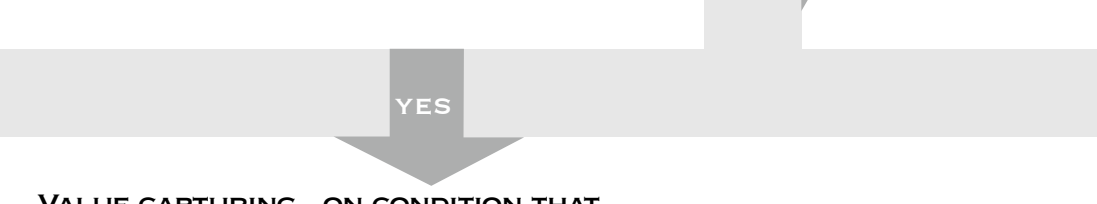

VALUE CAPTURING , ON CONDITION THAT

- GREen SPACES AND ADDED VAlue are INCORPORATED IN THE PROCESS AT AN EARLY STAGE
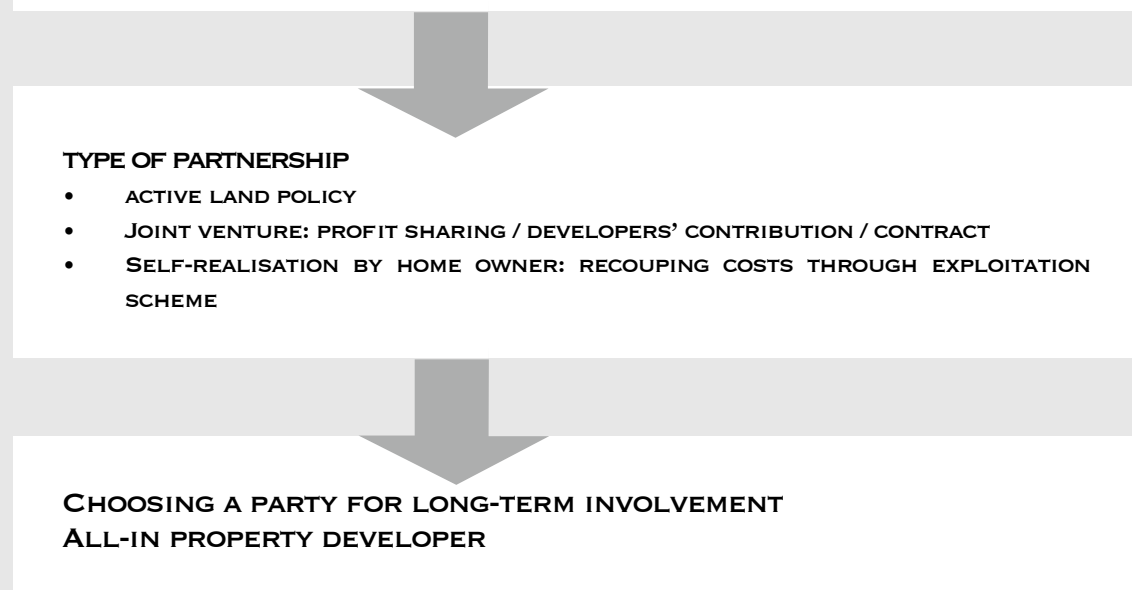

EXISTING REAL ESTATE

- taxes

- Property tax / Sewerage charge
6 PlanNiNg by SURPRISE:

\section{GREN SPACES SETTING THE AGENDA}

Spatial processes do not run a straightforward course or show regular patterns. Instead, they consist of periods of stability and a certain routine, interrupted by sudden major changes. That is why the VALUE project has investigated how these irregularities affect the planning process. This has resulted in a new vision on planning, called Planning by Surprise, in which green spaces can set the agenda.

Although planning processes are often regarded as linear paths, qualitative research in the VALUE project, involving interviews with planning experts, companies and public authorities, has shown that this path is often interrupted by unexpected events. Such an event is sometimes called a transition moment or a tipping point. It is a moment at which various things happen which suddenly make the situation far more complex. Questions are raised about the period of stability and routine, and a new playing field is created, resulting in a new period of stability and routine at a higher level of complexity

\section{TECHNICAL AND COMMUNICATIVE PLANNING}

The idea that planning follows a linear and logical course of development has had a long history. In the first half of the twentieth century, planning meant the technical exercise of producing a blueprint, and green spaces were largely the domain of agricultural engineers. After World War II, this approach no longer fitted in with the ever more dynamic nature of 
society. This led to the development of communicative planning, in which plans were seen as the outcome of a process of decision-making about building projects. Communication acted as a lubricant to get parties to agree without too much friction. And green spaces became one of the elements in the decision-making process.

The end of the twentieth century saw the birth of development planning, which focused on enabling spatial developments and creating new opportunities and chances, as opposed to the rigid restrictions imposed by the existing planning approach. Communication still played a major facilitating role, to promote smooth decision-making processes, but also as a means of involving people and companies in spatial developments. Green spaces were given a new role, offering added value to urban buildings and infrastructure, just as natural, recreational and historical values are important for multifunctional urban development. Green spaces and elements became a selling point.

\section{CHANCE AND SURPRISE}

Both of these views of planning, the technical as well as the communicative variety, shared one aspect: there was no part in it for chance or surprise. Everything was based on calculations and control. In technical planning, the master plan was the blueprint for changes, and planning studies yielded a factual 'truth', which could be expressed in figures, on which planning was then based. Communicative planning added the concept of strategic control to the decision-making process, with communication yielding the facts and truths that formed the basis for further planning. In these approaches, green spaces were also included on the basis of calculations and control. In technological planning, green spaces were included in the blueprint for urban development devised by agricultural engineers, whereas in communicative planning, green spaces were used in mathematical models as an element in the communicative strategy, as a counterbalance to housing and infrastructure. Time and again, the 'soft values' of green spaces - liveability, environment, ecology, historical values, recreation, health, etc. - were converted into hard Euros to enable them to be incorporated in planning calculations and steering.

FEELINGS, IMPRESSIONS, COINCIDENCE, PERSONAL RELATIONSHIPS AND POLITICAL CHANGES

In the technological and communicative planning approaches, governance was also mainly geared towards calculation and steering. These planning approaches are based on a governance style focusing on efficiency. Such a governance style is calculating, linear, structural and based on facts, and centres around a master plan or blueprint. There is no room for chance or surprise, or for personal views and emotions. The past ten years, however, have seen the growth of a new, adaptive style of governance, one that is more intuitive, nonlinear, based on ideas and beliefs, and intended to meet the challenges of ever-changing governments. Unlike previous styles, this style of governance is prepared for the unexpected and unpredictable. Thus, changes are taking place in the way planning and governance function. Planning processes have 
turned out to be far more unpredictable and uncontrolled than was assumed in the two historical planning approaches. Processes are highly dependent on 'tipping points' or transition moments, and such moments often produce a pressure cooker situation, in which many unexpected things occur. These changes are often dependent on 'soft' information, that is, feelings, impressions, chance occurrences, personal relationships, political changes, etc. Green spaces and elements often play a rather ill-defined role in these changes. Examples include the emotionally charged debate in the Netherlands about giving up polders to the sea to create new wetland habitats in compensation for civil engineering work elsewhere, or about finding locations for wind farms. Green spaces can make or break reputations and egos.

\section{DEPENDING ON 'SOFT' INFORMATION}

An example of a completely unexpected transition moment was the decision by the newly elected municipal executive of Amersfoort not to use the area around Randenbroek Park to build houses, but to designate it as a large green space. This more or less overturned the entire spatial planning process, forcing all parties involved to return to the drawing board. Whether this was a logical, calculating or steering type of decision is in fact not very relevant; what matters is that the decision meant an unexpected turn in the planning process. In taking such decisions, public officials often have to depend on 'soft' information. This kind of information has little to do with 'truth' or facts, unlike the 'hard' truths and facts that underlie the technical and communicative approaches to plan- ning, and is also difficult to grasp and to capture.

The VALUE project has tried to capture such soft information by means of in-depth interviews with parties involved in similar spatial processes in Stuttgart (Germany), Amersfoort and Manchester (UK), while focusing on the sensitive moments and situations. The interviews showed that such soft information reveals itself in phrases like 'Then suddenly there was a ..., "I still thought that ..., 'We put pressure on them ...', 'I then sensed that ...', 'After a glass of wine it turned out that he was not convinced at all...', 'The new alderman, however, ...'.

\section{BELIEFS AND PRAGMATISM}

In practice, the two governance styles (efficiency-oriented and adaptive) and different planning approaches co-occur, as is illustrated by two European examples, one from Germany and one from Britain. In Esslingen (Germany), the local authorities had developed a long-term planning strategy for the period up to 2027, while for pragmatic reasons, the actual realisation of the individual projects included in the strategy was left until the right moment. One of the projects in the long-term strategy was the construction of a cycle path along the river. When it turned out that the leader of a local political party was also the president of an angler's association, the authorities grasped the opportunity to make the river bank accessible by means of a cycle path that would also function as a meeting place for the anglers.

In Manchester, a property developer used a long-term strategy characterised by a belief in sustainable innovations. The developer invested in sustainable energy as a way to keep 
rents low and to make the real estate more attractive. They regarded the inclusion of well-designed and carefully maintained green spaces as important, especially since it would prevent depreciation of the property, rather than actually increase its value. At the same time, the company produced solid calculations for the measures that had to be taken to ensure sustainable energy supply.

\section{PLANNING BY SURPRISE}

As the above examples show, governance styles and planning approaches will continue to change, beliefs are supplemented with pragmatism and timing, and long-term and short-term strategies are implemented simultaneously. Both governance styles prove to be feasible and effective. Governing for efficiency ensures that spatial challenges actually result in new spatial interventions, concrete results that can be used to justify policies and governance, with newly created green infrastructure showing the success of the policy that was adopted, while the adaptive style of governance is more effective at the level of ideas, visions and strategies. Insisting that the economy needs green infrastructure leads to a collective conviction that green infrastructure is indeed necessary.

Planning by Surprise is thus not so much about making actual plans, but rather about designing a strategy that can be used to deal with change. Instead of focusing on one specific solution as a blueprint for solving the spatial challenge, Planning by Surprise implies that one continues to be on the lookout for all kinds of solutions that could make a positive contribution to the realisation of a long-term vision. In this approach, green infrastructure sets the agenda, as the belief in sustainability or a green long-term vision can, through pragmatic interventions at specific moments, be made to fit in seamlessly with various short-term economic, spatial, social, ecological or other objectives. Hard facts and data are required to develop a green infrastructure strategy based on figures about investments and the economic value of real estate and infrastructure. This means that green spaces and elements will never be completely decisive, but they can offer guidance for short-term projects. 
PUBLICATIONS BY VAN HALL LARENSTEIN, UNIVERSITY OF APPLIED SCIENCES, IN THE VALUE PROJECT

\section{ARTICLES}

CILLIERS, E.J., DIEMONT, E., STOBBELAAR, D.J. \& TIMMERMANS, W. 2010. Sustainable Green Urban Planning: The Green Credit Tool. In Journal of Place Management and Development, 3(1), ISSN: 1753-8335. March 2010. CILLIERS, E.J., DIEMONT, E., STOBBELAAR, D.J. \& TIMMERMANS, W. 2010. Stakeholder behaviour in Urban Development : Evaluating the Workbench Method. In Design and desicion support systems conference proceedings, Eindhoven, The Netherlands.

CILLIERS, E.J., DIEMONT, E., STOBBELAAR, D.J. \& TIMMERMANS, W. 2011. Enhancing sustainable development by means of the Workbench Method. In Environment and Planning B: Planning and Design, 38(4) 579 - 584.

CILLIERS, E.J., DIEMONT, E., STOBBELAAR, D.J. \& TIMMERMANS, W. 2011. Sustainable Green Urban Planning: The Workbench Spatial Quality Method. In Journal of Place Management and Development, 4(2), 214 224. ISSN: 1753-8335.

\section{REPORTS}

CILLIERS, E.J., DIEMONT, E., STOBBELAAR, D.J. \& TIMMERMANS, W. 2010. The Green Credit Tool report. (Value Added Planning, Volume 1). Part of the VALUE project (Valuing Attractive Landscapes in the Urban Economy, made possible by INTERREG IVB North West Europe, European Regional Development Fund, European Territorial Cooperation, 2007-2013. Wageningen UR, Van Hall Larenstein. 24p. 
CILLIERS, E.J., DIEMONT, E., STOBBELAAR, D.J. \& TIMMERMANS, W. 2010. The Workbench Method report. (Value Added Planning, Volume 2). Part of the VALUE project (Valuing Attractive Landscapes in the Urban Economy, made possible by INTERREG IVB North West Europe, European Regional Development Fund, European Territorial Cooperation, 2007-2013. Wageningen UR, Van Hall Larenstein.

CILLIERS, E.J., DIEMONT, E., STOBBELAAR, D.J. \& TIMMERMANS, W. 2011. The Value Added Planning report. (Value Added Planning, Volume 3). Part of the VALUE project (Valuing Attractive Landscapes in the Urban Economy, made possible by INTERREG IVB North West Europe, European Regional Development Fund, European Territorial Cooperation, 2007-2013. Wageningen UR, Van Hall Larenstein. 55p.

\section{AS YET UNPUBLISHED ARTICLES}

CILLIERS, E.J. \& TIMMERMANS, W. 2012. Approaching Value Added Planning in the Green Environment. In Journal of Place Management and Development. ISSN: 1753-8335.

CILLIERS, E.J. \& TIMMERMANS, W. 2012. Value Added Planning: Planning beyond Development. In Journal of Development Studies.
THE FOCUS MUST BE ON

THE PLANNING PROCESS ITSELF, NOT ON ITS IMMEDIATE PROCEEDS. THIS WAS THE MAIN CONCLUSION THAT THE AMERSFOORT LOCAL AUTHORITIES DREW ABOUT THE USE of VAlue Added PlanNing. ALTHOUGH DIRECT ECONOMIC GAINS FROM GREEN INFRASTRUCTURE ARE HARD TO CALCULATE, ADDED VALUE CAN BE ACHIEVED BY I NVIT'I NG A RANGE OF DISCIPLINES TO BECOME INVOLVED IN THE PLANNING PROCESS RIGHT FROM THE START 

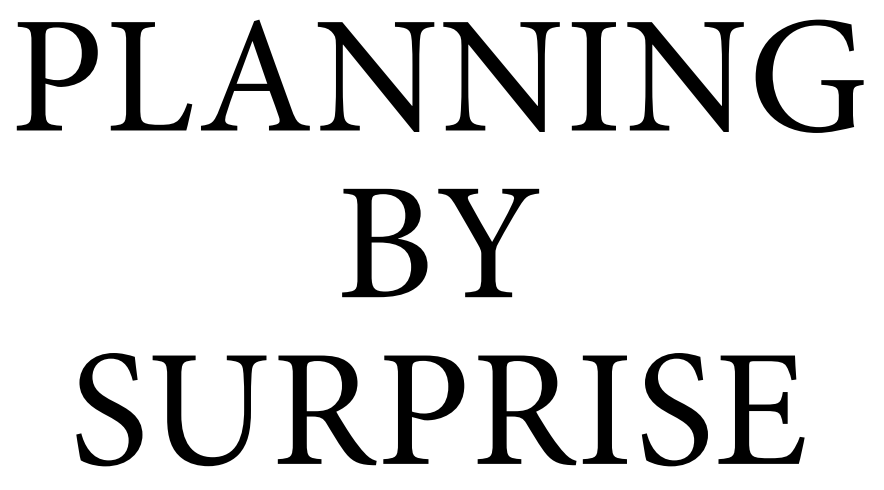

images of the green city

Photo merge

Jos Jonkhof 


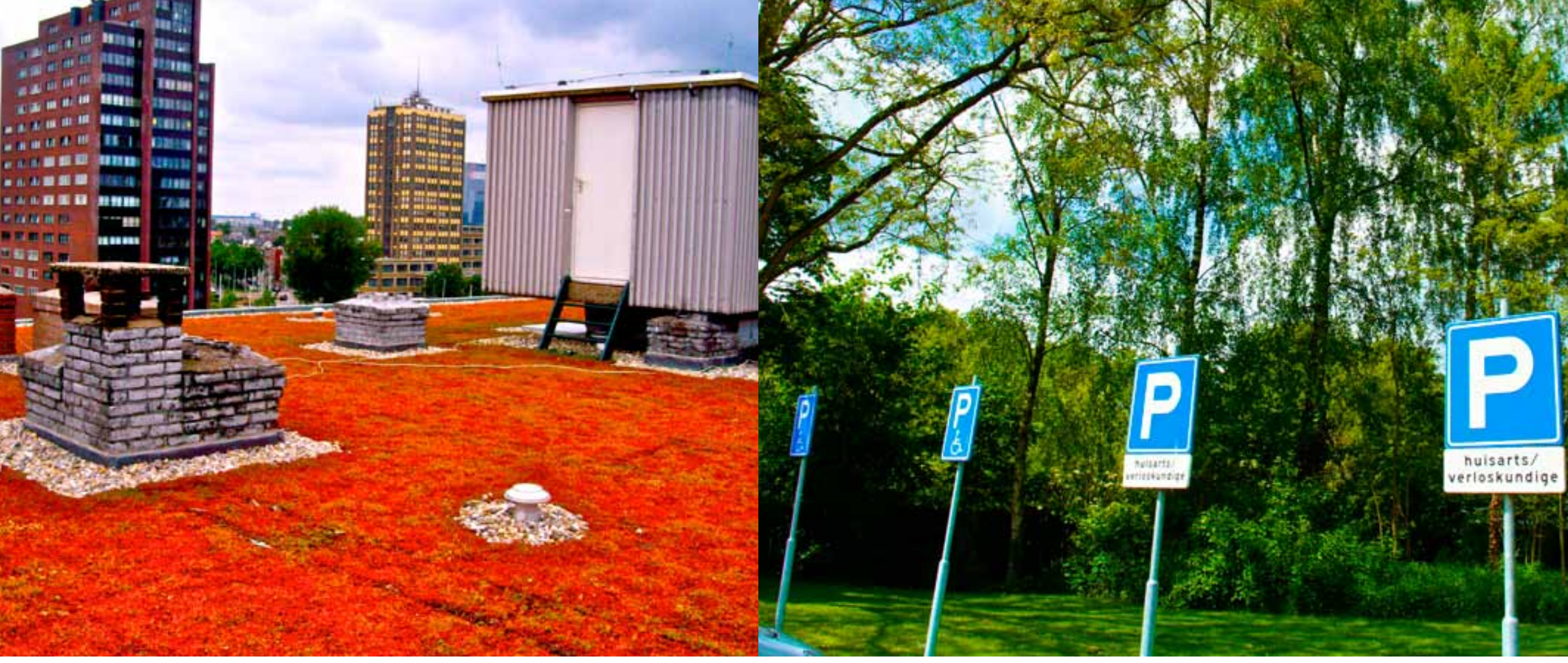

GREEN URBAN SPACES ARE FOUND IN ALL KINDS OF PLACES, BUT

IS THIS REALLY WHAT GREEN CITIES ARE SUPPOSED TO LOOK LIKE?
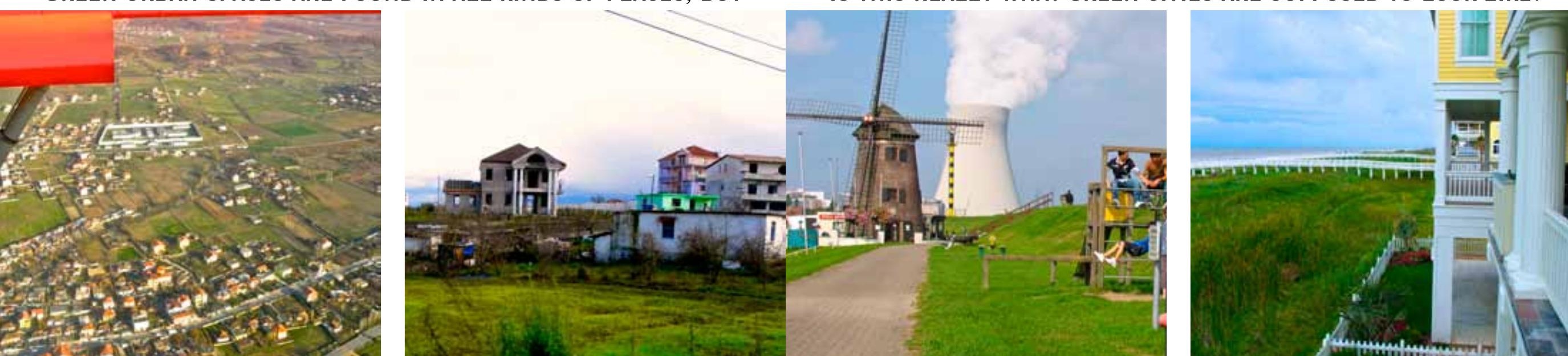

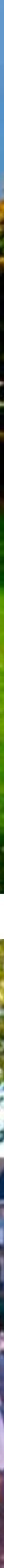


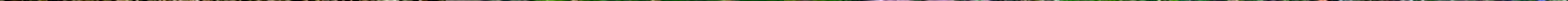



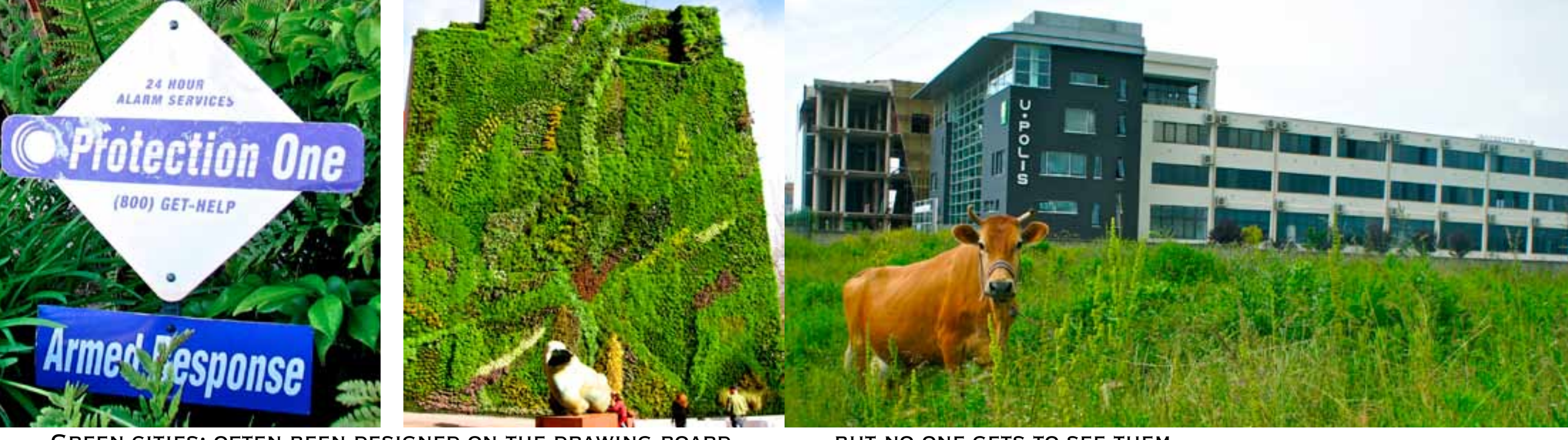

GREEN CITIES: OFTEN BEEN DESIGNED ON THE DRAWING-BOARD,

BUT NO-ONE GETS TO SEE THEM
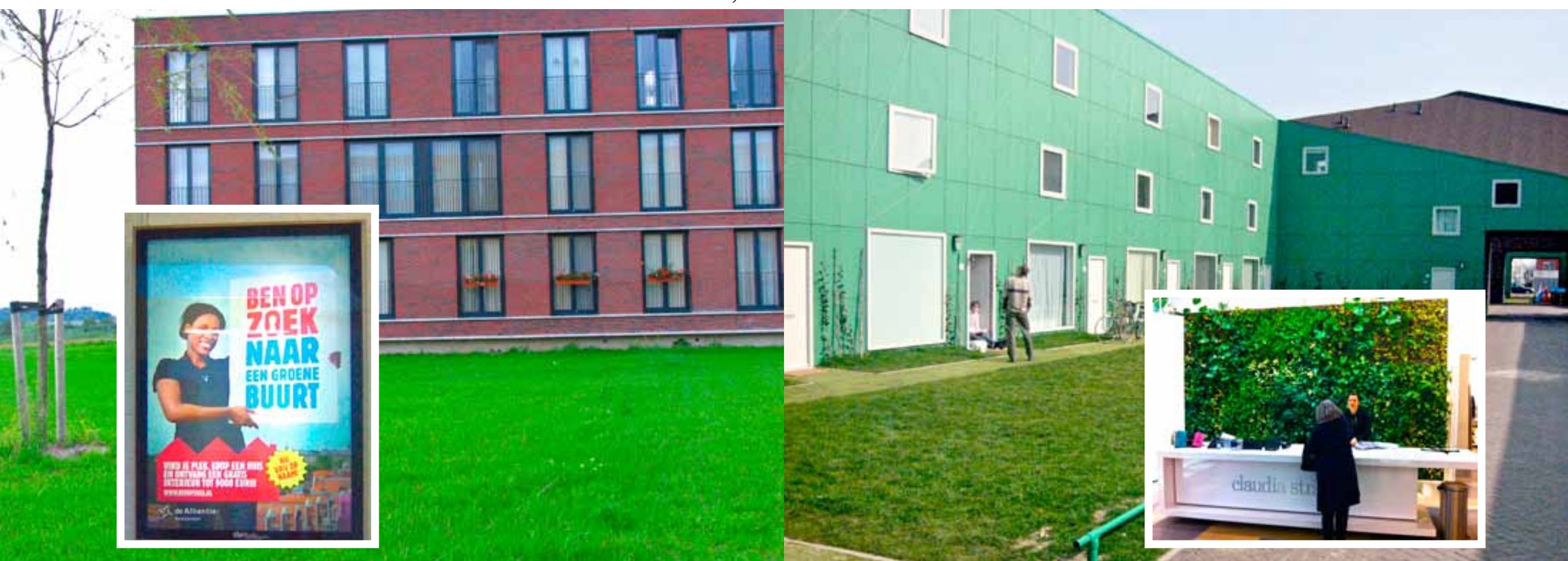


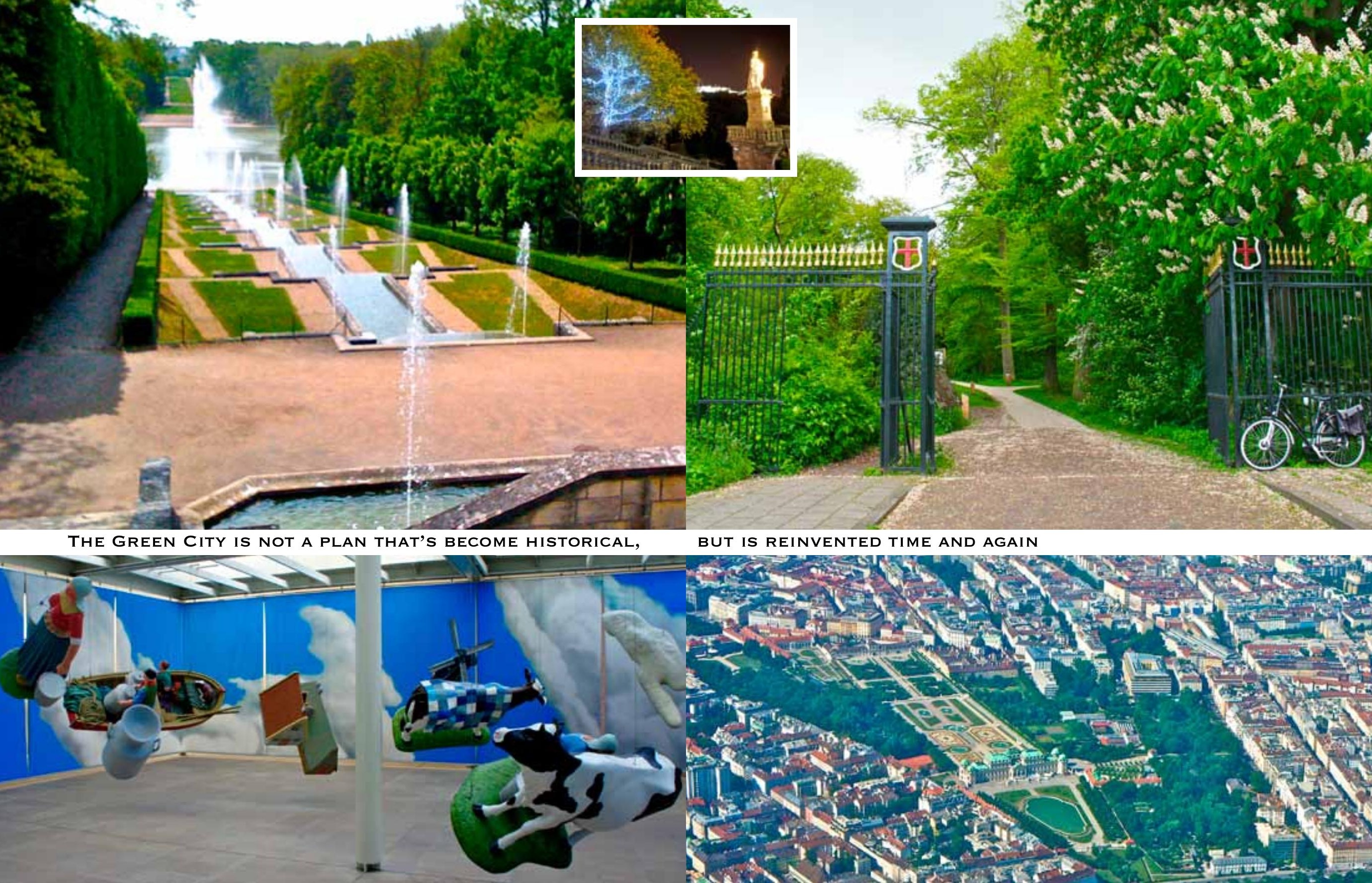




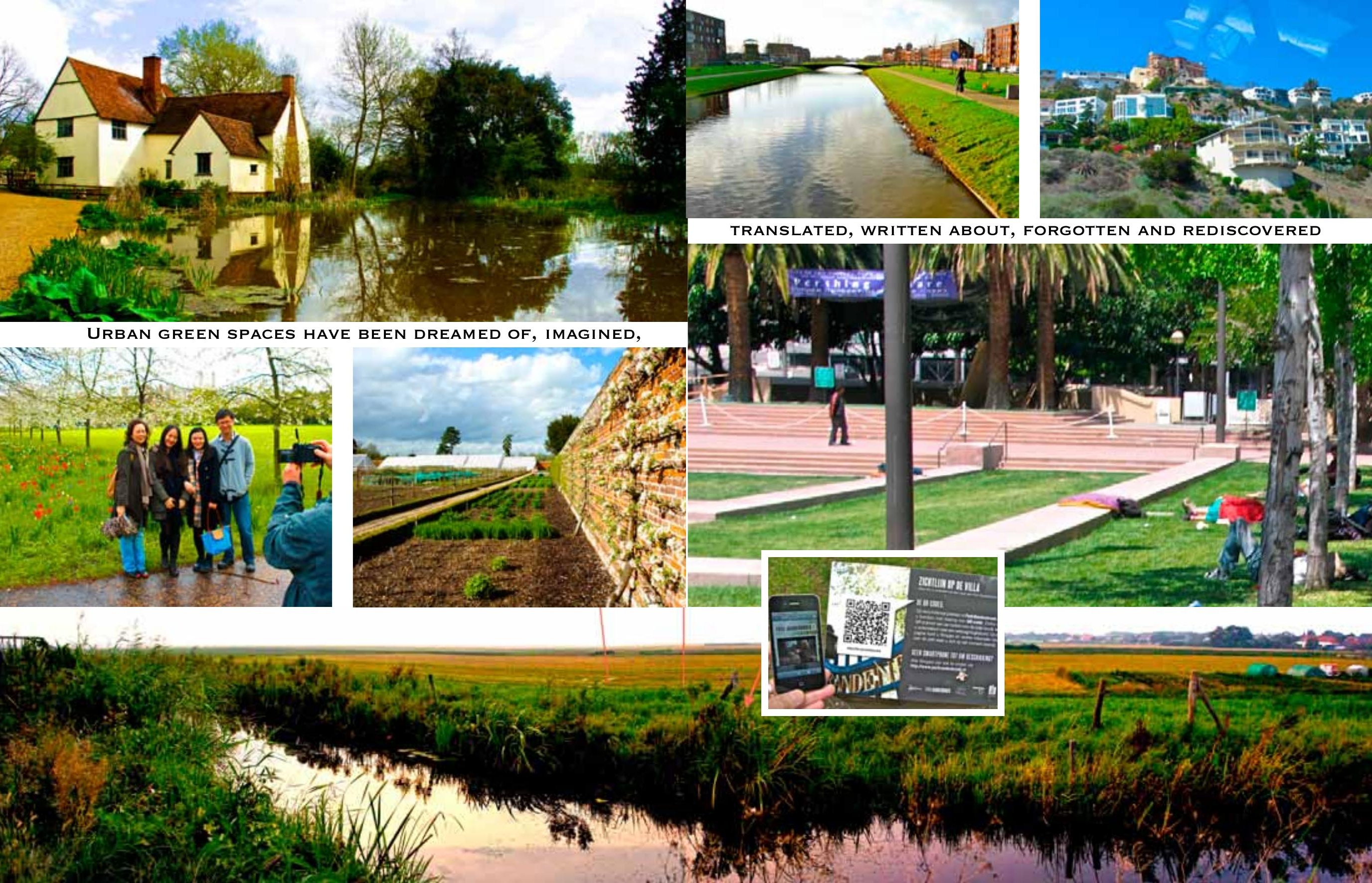



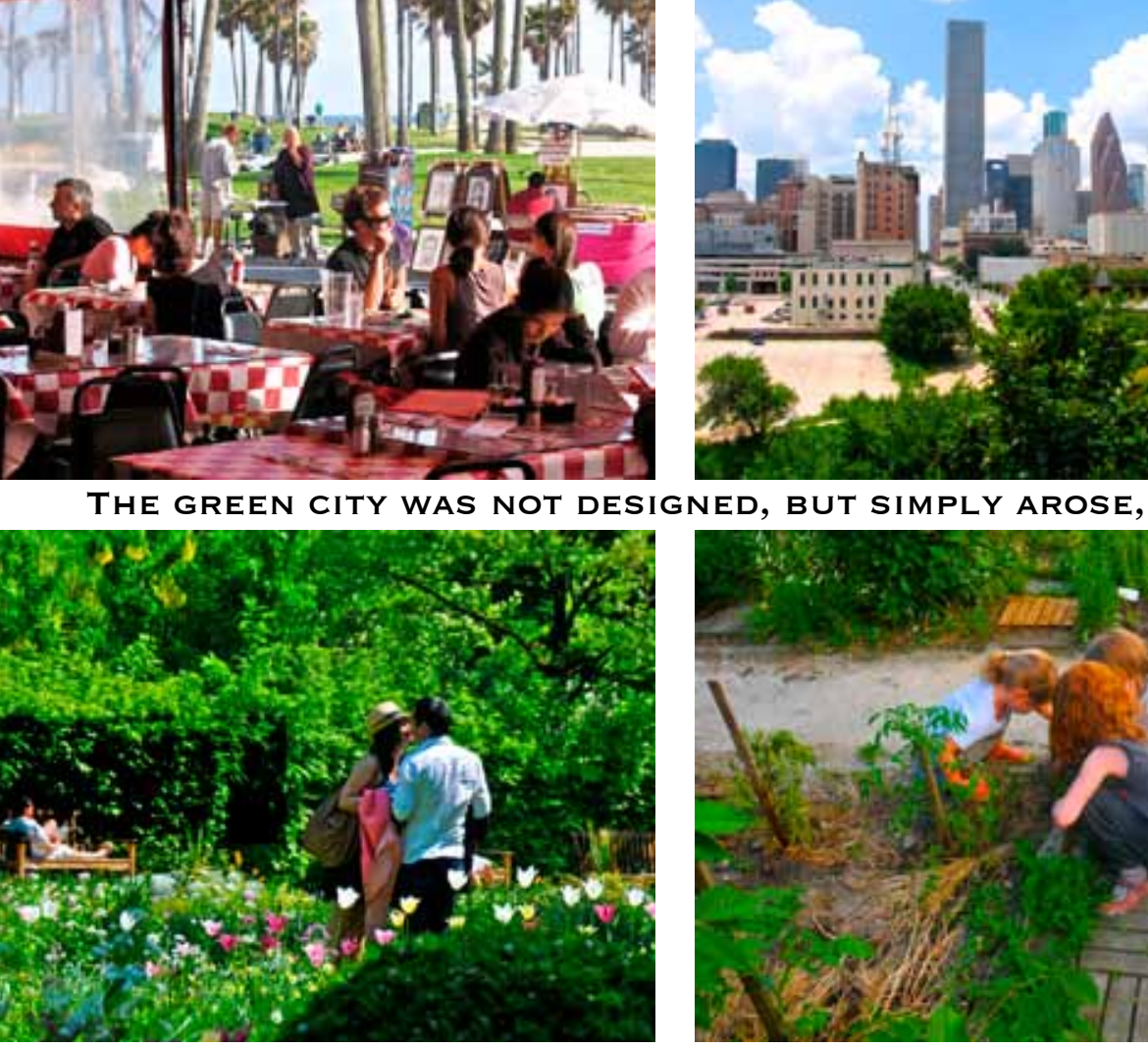

\section{THE GREEN CITY WAS NOT DESIGNED, BUT SIMPLY AROSE,}

BY ACCIDENT, FROM GREAT VISIONS AND HIGHER GOALS

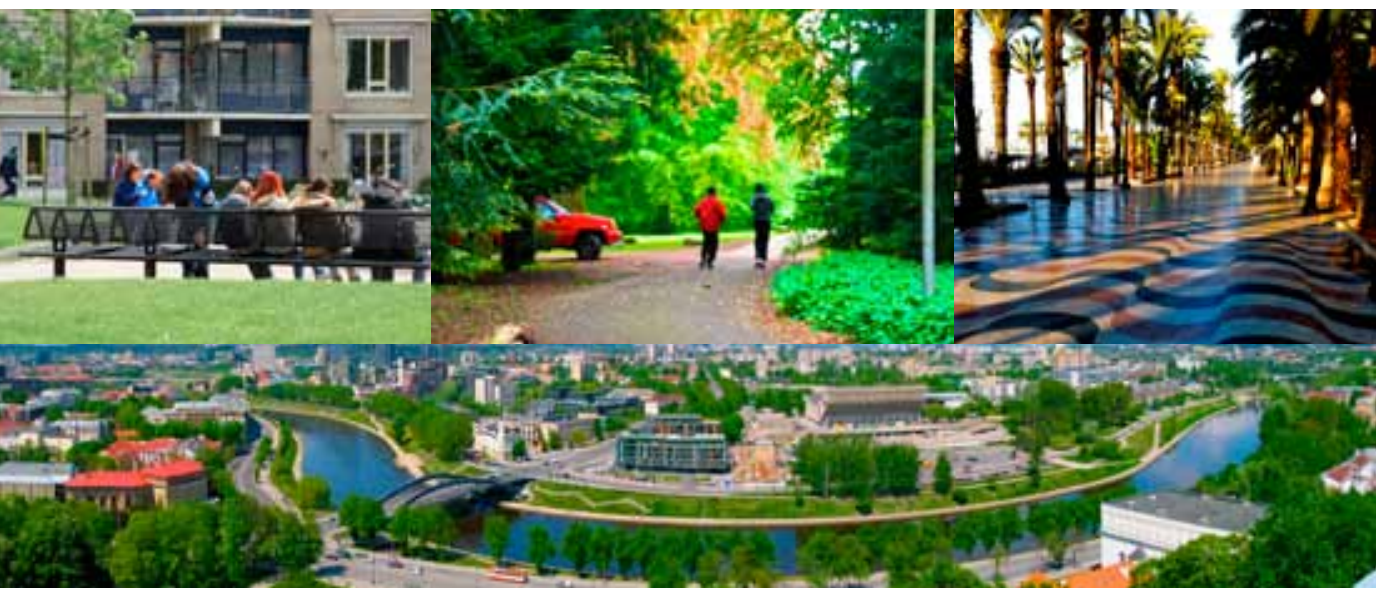

